\title{
展開反カを考慮した宇宙インフレータブル構造物の展開制御法*1 Deployment Control of Space Inflatable Structures Considering Reaction Forces
}

\author{
中島啓 $2 * 3$ ・渡辺和樹*4 • 角田博 明*5 • 山川 宏*2
}

Akira NAKAJIMA , Kazuki WATANABE , Hiroaki TsunODA and Hiroshi YamaKAWA

Key Words: Space Engineering, Inflatable Structure, Deployment Control

\begin{abstract}
In the process of deployment of an inflatable structure, when the stiffness of the structure increases rapidly, especially at the final moment of deployment, a large reaction force is generated around supporting points with the main body of a spacecraft. It is important to minimize the reaction force when deploying in order to decrease the influence on the satellite attitude and strength of supporting points as much as possible. The purpose of this study is to attain a method of optimal deployment control that minimizes the reaction force generated around supporting part. In order to achieve the goal, feedback control experiments using an electromagnetic valve to adjust the inner pressure was done during deployment of inflatable tube. In addition, the effectiveness of the proposed method was also examined when applying it to the structure of the different size. As a result, it is found that the suppression of the reaction force is attained by about $80 \%$ compared with the case where this control is not applied, and the effectiveness of the proposed feedback control method of inner pressure was confirmed. Moreover, considering the volume, it is able to apply this control method even with different scale structures.
\end{abstract}

\section{1. はじめに}

太陽電池パネルやアンテナなどの宇宙構造物は寸法を大 きくすることでその性能を向上させることができるために， 近年宇宙構造物の大型化・軽量化の需要が高まっている. しかし宇宙構造物は打ち上げ時にロケットに搭載できる容 積や質量に制限があり，大型化のためには軽量材料を用い て展開式にする必要がある，そこで宇宙空間において大規 模構造物を構成するのに適している特徵を持ったインフレ ータブル構造物に注目が集まっている．インフレータブル 構造物とは軽量材料を用いた柔軟な膜状構造物を地上にお いて小さく折り畳み，宇宙空間においてガス等により膨張 展開させ所望の形状を構築するものである。この構造は軽 量・高収納率・機構部品の少なさによる低コス卜化などさ まざまな利点をもたらす。しかし現状においては，「イン フレーション挙動の不安定さ」「内圧低下による展開終了 後の剛性損失」「スペースデブリによるガスリーク」など の問題を有しており, 現在, 解決に向けて活発に研究が行わ れている，中でも, 展開を安定的に行うことは, 展開信頼性 を高くするうえで重要であり，折り畳み方法を工夫したり 展開を制御する方法が研究されている ${ }^{1 \sim 3)}$. 特に展開時の 挙動については, 折り畳夕方や材質の違い ${ }^{4,5)}$ が展開性能に

\footnotetext{
*1C2010 日本航空宇宙学会

平成 20 年 11 月 7 日，第 52 回宇宙科学技術連合講演会にて発表

平成 21 年 7 月 13 日原稿受付

*2 早稲田大学創造理工学研究科

*3 現 コマツ工機

*4 ウェルリサーチ

*5 東海大学工学部
}

与える影響を調べる実験，また展開シミュレーション 6 9) やモデル化 ${ }^{10)}$ など, さまざまな研究が行われている. 一方, インフレータブル構造が展開する時の支持部に生じる反力 に注目した研究は，インフレータブル構造の薄く軽量な膜 状構造の特徵ゆえほとんど行われてこなかった。しかし実 際にはインフレータブル構造の展開過程，特にその最終段 階において構造物の剛性が急速に高まり，宇宙船本体との 取り付け点などで大きな反力が発生する恐れがある．衛星 姿勢や取り付け点強度への影響を極力低減させるために, 展開時の反力を評価しその大きさを低減させることは重要 である，そこで本研究では，インフレータブルチューブの 展開中の内圧を用いた電磁弁のフィードバック制御による 展開時のガス流量の調整により，展開時の反力の低減を行 う。展開制御の方法については流量を制御する方法以外に も考えられるが，流量により制御を行うことで，大掛かり な装置が不要であり，制御装置の構成が簡素なものとなる ため，軽量・高収納率というインフレータブル構造の特性 を有効に活用できるという利点があげられる。この流量制 御という簡便な手法を用いて，発生する支持部反力を極力 低減する展開制御方法を構築し，反力低減の可能性を示寸 ことを本研究の目的とする。また得られた制御方法を，相 似的に大きくした構造物に適用し，本制御方法適用の有効 性を明らかにする。

\section{2. 実 験 装 置}

2.1 装置概略 本実験において用いた実験装置の概略 
図を第 1 図に示す．圧縮空気ガスボンベより空気ガスを供 試体であるインフレータブルチューブへ流入し，供試体の 支持部に取り付けた 6 軸力覚センサにより展開時の反力を 測定する．その際に電磁弁が全開放であるときの流量を 30 L/min となるよう設定し，電磁弁の開閉制御により流量を 調整する。電磁弁の制御には PIC マイコンを用いて，適宜 チューブ内の内圧を読み取りフィードバック制御を行う. また，重力の影響を補償するために供試体上部にへリウム ガス風船を取り付けた。

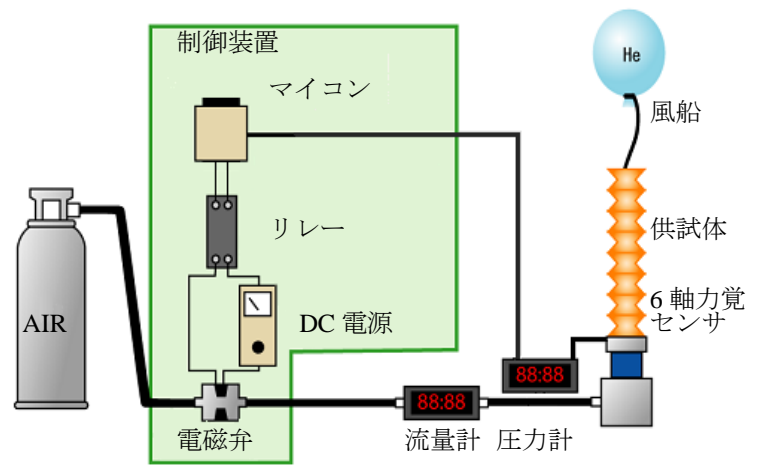

第 1 図 実験装置概略図

2.2 供試体 本実験では形状として基本的な構造要素 であること，また太陽電池パドルやアンテナなどの支持構 造に幅広く適用可能であることから，円筒チューブ型のイ ンフレータブル構造物を用いて実験を行う。第 2 図にイン フレータブル構造物の概観を，第 1 表にその諸元を示寸. また，供試体上面から見た図を第 3 図に示す。構造物の均 一性を保つためフィルムと同素材のテープをチューブ両端 に貼り，図のように座標軸を設定する．チューブの折り畳 み方は制御時との反力の差異をより顕著にするため, 他の 多角形折りなどと比較し展開挙動が大きくなる Z 折り ${ }^{4)}$ と する. Z 折りとはインフレータブルチューブをジグザグに 畳んでゆく折り方で，実験で用いる供試体において折り目 線はY軸方向となるようにする。第 4 図に折り目線を，第 2 表に各供試体における折り目線の位置を示寸。また，供 試体作成直後は反力にばらつきがみられた。これは供試体 作成直後の折り目の位置が不安定となるため生じるものと 考えられる。このため, 反力が安定するまで流入排出を繰 り返し反力の安定が得られた状態で実験を行った.

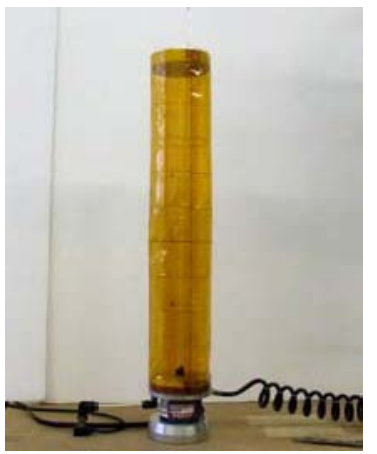

材質 ポリイミド

厚さ $25 \mu \mathrm{m}$

ヤング率 $3.4 \mathrm{GPa}$

供試体 $\alpha, \beta$

全長/直径 $400 / 80 \mathrm{~mm}$

供試体 $\gamma$

全長/直径 600/120 mm
第 1 表 供試体諸元

\begin{tabular}{ccccc}
\hline & $\begin{array}{c}\text { 全長/直径 } \\
(\mathrm{mm})\end{array}$ & $\begin{array}{c}\text { チューブ質 } \\
\text { 量 }(\mathrm{g})\end{array}$ & $\begin{array}{c}\text { ふたの質量 } \\
(\mathrm{g})\end{array}$ & $\begin{array}{c}\text { 全質量 } \\
(\mathrm{g})\end{array}$ \\
\hline 供試体 $\alpha$ & $400 / 80$ & 5.08 & 3.82 & 8.90 \\
\hline 供試体 $\beta$ & $400 / 80$ & 5.06 & 3.86 & 8.92 \\
\hline 供試体 $\gamma$ & $600 / 120$ & 11.4 & 7.55 & 18.9 \\
\hline
\end{tabular}

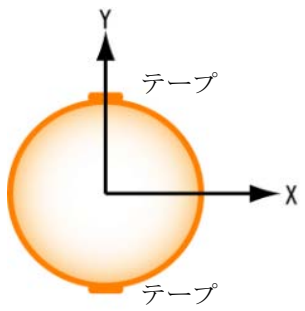

第 3 図 供試体上面図

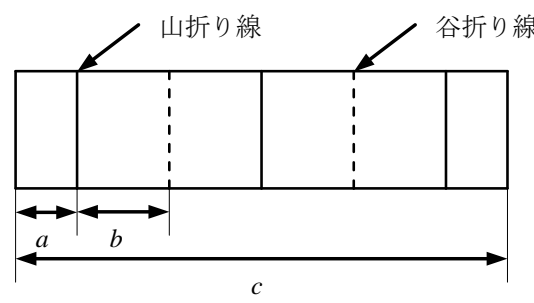

第 4 図 供試体の折り目線

第 2 表 各供試体の折り目線の位置

\begin{tabular}{cccc}
\hline & \multicolumn{3}{c}{ 各寸法の值 $(\mathrm{mm})$} \\
\cline { 2 - 4 } & $a$ & $B$ & $c$ \\
\hline 供試体 $\alpha, \beta$ & 40 & 80 & 400 \\
\hline 供試体 $\gamma$ & 60 & 120 & 600 \\
\hline
\end{tabular}

2.3 電磁弁の制御 本実験においては，マイコンを用 いて電磁弁に印加寸るパルス波を生成し，そのデューティ 一比を変化させることで流量の制御を行う。マイコンによ り生成する電磁弁制御のパルスを第 5 図に示す。また弁開 放割合と流量の関係を第 6 図に示寸。第 6 図における目標 值とは，電磁弁の全開時と全閉時の流量を比例補間したも のである。

2.4 測定の精度 本実験において用いた 6 軸力覚セン サの分解能は約 $0.006 \mathrm{~N}$ である.よって測定結果は小数点 以下 2 桁にまとめることとする。本実験では，供試体作成 時の誤差や折り目位置のずれにより供試体ごとに個体差が あると考えられるため，反力の絶対值という観点からの実 験の再現性は低いと考えられる。しかし，反力のレンジは 異なっていても，展開時の基本的な特性は同様であること から流量による特性に関しては再現性を有していると考え られる。 


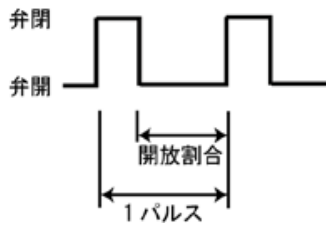

第 5 図 電磁弁制御パルス

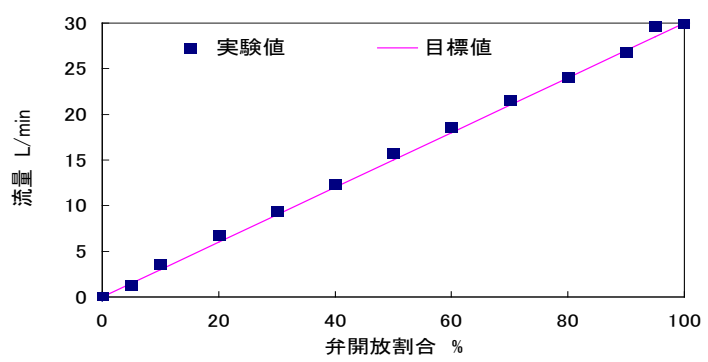

第 6 図 弁開放割合と流量の関係

\section{3. 展 開制 御 実験}

3.1 予備実験 インフレータブルチューブ展開時の基 本的な特徵を確認するため, 制御を行わずに展開した時の 反力と内圧の変化を測定する。ここでは電磁弁の開放割合 を $100 \%$ (30 L/min) として展開を行う。なお次節の制御開始 タイミング検討においては供試体 $\alpha$ を用い，それ以降の実 験においては供試体 $\beta$ を用いた。これは実験の繰り返しに よって供試体の劣化と破損が発生したためである. 第 7 図 に供試体 $\beta$ の $Y$ 軸方向についての反力の時間推移を，第 8 図に展開時の内圧の時間推移を示寸.また，第 9 図に同条 件にて測定した $Y$ 軸方向の反力の展開完了時の約 0.4 秒間 の抜粋図を，第 10 図に反力の周波数分布を示す. 第 7 図よ り展開完了時のチューブが大きく変形した瞬間に最大反力 が生じていることがわかる，逆に展開開始後からの膨張時 には反力がほとんじ生じていないことが確認でき，供試体 $\alpha, \beta$ それぞれの $X$ 軸， $Y$ 軸についてこれらと同様の特徵 が確認された。 反力については，展開時の首振りによる慣 性の影響や塑性変形した折り目の伸びによる影響などの複 合的な要因が挙げられ，特定することは困難であるが，第 10 図に示した反力の周波数分布より, 特定の周波数帯にピ 一クを持つことから，供試体の振動が反力に影響を与えて いることが考えられる。この供試体の振動については，折 り目を有する構造ゆえ複雑な振動モードを有していると推 測でき，この振動と反力や挙動についての関係性を明らか にしていくことはインフレータブル構造物について議論し ていく中で重要であり, 今後の課題である.以上を鑑みて, 本実験においては，振動と反力・展開挙動についての関係 性を明らかにしていくことの前段階として，複雑な振動モ ードの中でも，円筒形はりに類似した振動モードに影響す ると考えられる展開時の首振りや，より高次の振動モード に影響すると考えられる塑性変形した折り目の伸びを，流
量の調節により最終段階をゆっくり展開させることにより, 反力の低減化を狙いとし，検討していくこととする．また 第 8 図より内圧についても展開中の上昇は過去の研究 ${ }^{8,9)}$ と同様に微増にとじまっており，展開が完了する瞬間に急 激に上昇していることがわかる，供試体 $\alpha$ と供試体 $\beta$ にお いて反力に差異が確認されたが，その理由としては，供試 体の作成精度の誤差によるものと考えられる．具体的に述 ベると，薄膜であるポリイミドフィルムを円筒形につなぎ あわせる際のずれや折り目位置のずれが影響を与えている と考えられる. また，風船による微小重力模擬の妥当性に ついて述べると，風船の振動などが反力に影響を与えると するならば，風船のひもがある程度の長さを有しているこ とより,第 10 図において低周波数帯の強度が高く出ること が考えられる．しかし，そのようにはなっておらず，風船 の挙動によって反力に影響を与えていることは考えにくく， 反力に注目する限りにおいては，風船による微小重力模擬 の妥当性がうかがえる.

3.2 制御開始タイミング検討 先の予備実験より展開 終了直前以外の供試体の膨張過程においては流量が反力に ほとんど影響していないと考えられ，展開の途中において 制御を行ってもその効果はあまり期待できない。また，イ ンフレータブル構造物は展開中に外乱の影響を受けやすい 状態にあると考えられ，展開時間が長くなるのは好ましい ことではない. よって制御開始のタイミングについて検討 をする．反力への影響が少ない範囲を測定するために，は じめ最大流量である $30 \mathrm{~L} / \mathrm{min}$ で展開を開始し供試体体積の 一定割合まで流入後に弁開放割合を $30 \%$ (約 $10 \mathrm{~L} / \mathrm{min}$ ) とし, この最大流量で流入する割合を変化させ最大反力を測定す る，例をあげれば，最大流量での流入割合 $0 \%$ とは展開開 始から流量を $10 \mathrm{~L} / \mathrm{min}$ とすることである. 結果を第 11 図 に示す、第 11 図よりチューブ体積 80 \%を境界に反力が上 昇していることがわかる．よって制御開始のタイミングを チューブ体積 80 \%流入後とすれば良いが，以降の制御の一 般性を考慮し，余裕をもたせ，制御開始のタイミングをチ ユーブ体積 70 \%流入時点として以降の実験を行うことと する.

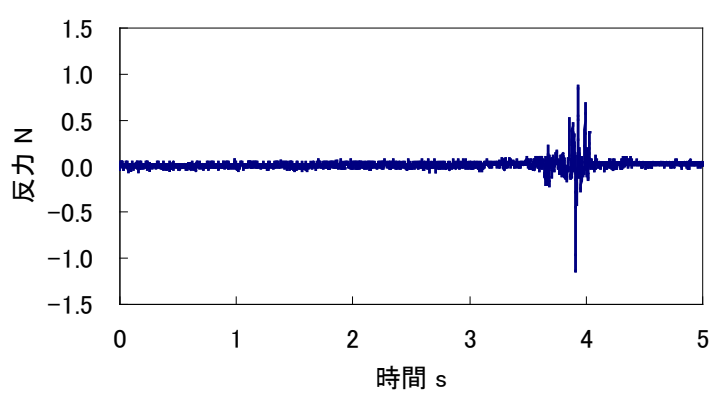

第 7 図 反力の時間推移(供試体 $\beta, Y$ 軸方向, 制御なし) 


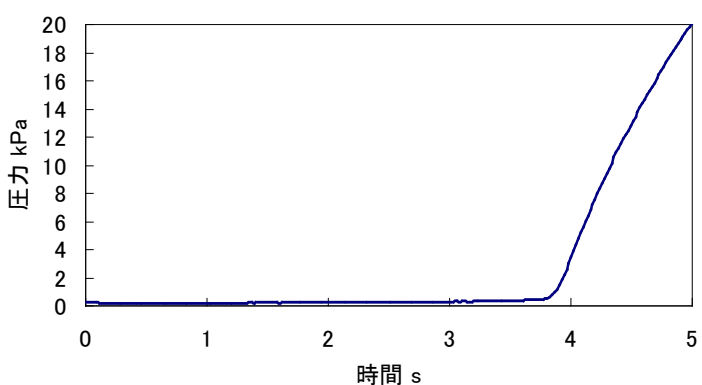

第 8 図 圧力の時間推移(供試体 $\beta$, 制御なし)

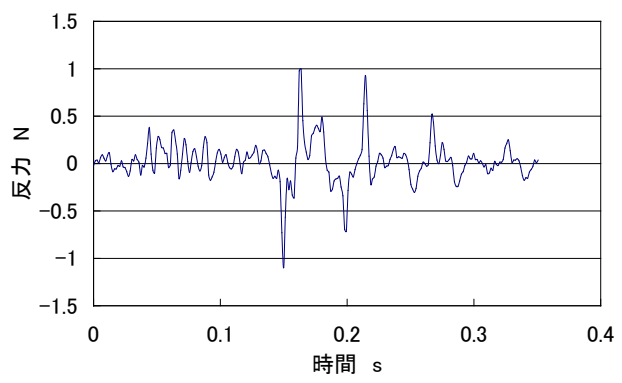

第 9 図 反力の時間推移(供試体 $\beta, Y$ 軸方向，一部抜粋)

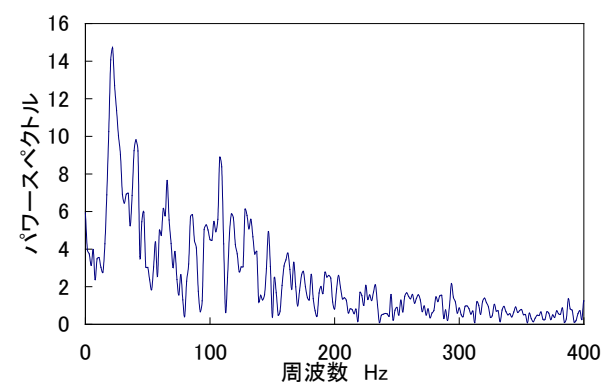

第 10 図 反力の周波数分布

3.3 最適流量測定実験 展開完了時における流量と反 力の関係について検討を行うために，次のような条件で実 験を行う。当初流量は最大流量である $30 \mathrm{~L} / \mathrm{min}$ にて制御開 始となる供試体の体積割合 $70 \%$ まで流入させ, 制御開始後 に各種設定した弁開放割合に変化させてそれぞれの最大反 力を測定する. その際，流入開始前の初期内圧に対して 0.2 $\mathrm{kPa}$ 上昇で流入停止, 初期内圧に対する上昇分が $0.2 \mathrm{kPa}$ を 下回ると流入再開となるように，内圧上昇值に対するガス 流入のオン／オフ・フィードバック制御を適用する。流入 開始直前の内圧を基準としたのは，供試体内部の残存気体 の完全排出が困難なためである。また，本実験において内 圧の判定基準を $0.2 \mathrm{kPa}$ としたのはマイコンと圧力センサ の分解能の限界を用いたからである。なお本研究における 内圧制御の目的は，展開完了時の反力を低減させることを 第一義的に考えており，展開完了時の反力の発生と同時に 生じる内圧上昇の初期段階をとらえることで流入を一時停
止させ，最終段階をゆっくり展開させることで反力を低減 させることを考えている。したがって，展開完了時の流入 量と内圧は制御の有無において同一となることを前提とし ていない. 実験結果を第 12 図に示す.また内圧によるフィ ードバック制御の有効性を確認するために，弁開放割合 $10 \%$ \%おける展開で，フィードバック制御を行わなかった 時の展開反力についても測定を行った。その比較を第 3 表 に示す。第 12 図は制御開始後の弁開放割合を $10 \%$ (3.65 L/min)以下とすることで反力の低減が可能であることを示 している．つまり展開完了時の反力が上昇する瞬間の流量 を $3.65 \mathrm{~L} / \mathrm{min}$ とすることで反力を減少することができるこ とを示している。また第 3 表においてフィードバック制御 の有無による反力の差異からも内圧によるフィードバック 制御の有効性が確認できる。

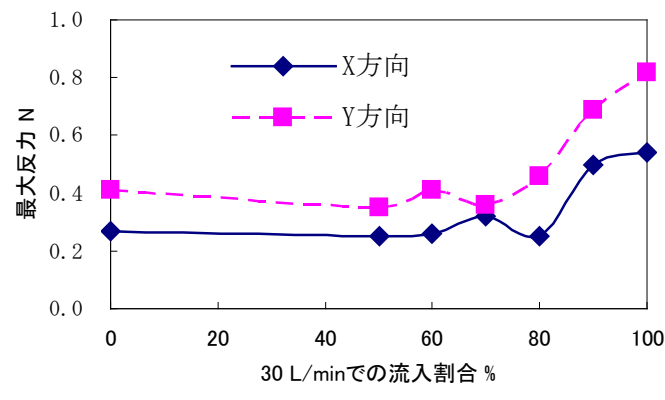

第 11 図 最大流量での流入量と最大反力の関係

3.4 最適制御パターン検討 前述のようにインフレー タブル構造物の展開途中は外乱の影響を受けやすく不安定 であると言え，展開時間の短縮は重要である，そこで前節 においての制御開始後の弁開放割合を 10 \%とするパター ンを基本とし，より展開時間を短縮するためにさまざまな パターンについて検討を行った．結果を第 4 表に示す．前 節の結果より，反力を最も低減することができる弁開放割 合 $10 \%$ (流量 $3.65 \mathrm{~L} / \mathrm{min}$ ) となるときのチューブ体積に注目 する．第 4 表より，パターンA では弁開放割合 $10 \%$ とな るときのチューブ体積は 85 \%となっているが反力の低減 はできていない. 次にチューブ体積 $80 \%$ \%おいて弁開放割 合 $10 \%$ となるようなパターン (B, C, D)について実験した結 果，反力を基本のパターンとほぼ同程度まで抑えることが できていることがわかる．特にパターンC はチューブ体積 80 \%まで最大流量でガスを流入したものでありこの条件 においては展開時間の最も速い制御である。これより，チ ユーブ体積 80 \%において弁開放割合 $10 \%$ となっていれば 最小の反力が得られることが示されており，この結果は夕 イミング測定実験における結果とも整合性がみられる。展 開速度においてはパターン C が最も優れているが，異なる 寸法の供試体への本制御の適用を考慮し，徐々に流量を減 少させ，制御に余裕を持たせたパターン D について次章以 降制御の一般性を検討してゆく，パターン A, B , C, D の詳 
細について第 5 表〜第 8 表に示す.また, パターン D にお ける $Y$ 軸方向の展開反力の時間推移を第 13 図に示す. パ ターン D の制御を用いることで, 供試体 $\beta$ の $Y$ 軸方向にお ける最大反力を, 制御なし時の $1.14 \mathrm{~N}$ に対して, $0.23 \mathrm{~N}$ に 低減されていることがわかる.

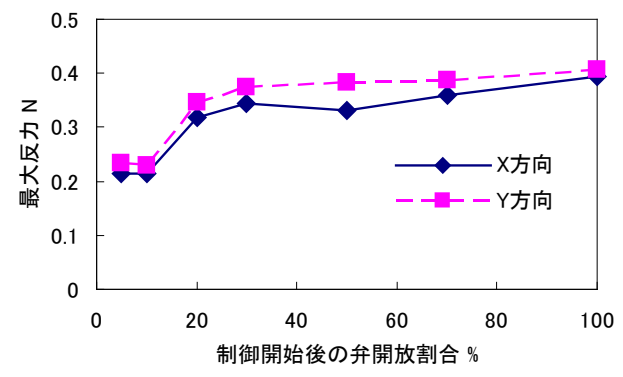

第 12 図 制御開始後の弁開放割合と最大反力

第 3 表 内圧による制御の有無による最大反力の違い

\begin{tabular}{cccc}
\hline 弁開放割合 & 内圧によるフィ & \multicolumn{2}{c}{ 最大反力 $(\mathrm{N})$} \\
\cline { 3 - 4 }$(\%)$ & 一ドバック制御 & $X$ 方向 & $Y$ 方向 \\
\hline 100 & 無 & 0.89 & 1.14 \\
\hline 100 & 有 & 0.39 & 0.41 \\
\hline 10 & 無 & 0.32 & 0.38 \\
\hline 10 & 有 & 0.21 & 0.23 \\
\hline
\end{tabular}

第 4 表 各パターンでの測定結果

\begin{tabular}{|c|c|c|c|c|}
\hline \multirow[t]{2}{*}{ パターン } & \multirow{2}{*}{$\begin{array}{c}\text { 流量 } 3.65 \mathrm{~L} / \mathrm{min} \text { と } \\
\text { なるときの体積 (\%) }\end{array}$} & \multicolumn{2}{|c|}{ 最大反力 $(\mathrm{N})$} & \multirow{2}{*}{$\begin{array}{l}\text { 理論展開 } \\
\text { 時間 (s) }\end{array}$} \\
\hline & & $X$ 方向 & $Y$ 方向 & \\
\hline 基本 & 70 & 0.21 & 0.23 & 12.73 \\
\hline $\mathrm{A}$ & 85 & 0.37 & 0.39 & 9.71 \\
\hline $\mathrm{B}$ & 80 & 0.24 & 0.26 & 10.71 \\
\hline $\mathrm{C}$ & 80 & 0.21 & 0.29 & 9.83 \\
\hline D & 80 & 0.22 & 0.23 & 10.53 \\
\hline
\end{tabular}

第 5 表 パターン A 詳細

\begin{tabular}{ccc}
\hline 弁開放割合 $(\%)$ & 流入割合 $(\%)$ & 累積流入割合 $(\%)$ \\
\hline 100 & 70 & 70 \\
\hline 50 & 5 & 75 \\
\hline 30 & 5 & 80 \\
\hline 20 & 5 & 85 \\
\hline 10 & 展開完了まで & 展開完了まで \\
\hline
\end{tabular}

第 6 表 パターンB 詳細

\begin{tabular}{ccc}
\hline 弁開放割合 $(\%)$ & 流入割合 $(\%)$ & 累積流入割合 $(\%)$ \\
\hline 100 & 70 & 70 \\
\hline 50 & 5 & 75 \\
\hline 20 & 5 & 80 \\
\hline 10 & 展開完了まで & 展開完了まで \\
\hline
\end{tabular}

第7表 パターンC 詳細

\begin{tabular}{ccc}
\hline 弁開放割合 $(\%)$ & 流入割合 $(\%)$ & 累積流入割合 $(\%)$ \\
\hline 100 & 70 & 80 \\
\hline 10 & 展開完了まで & 展開完了まで \\
\hline
\end{tabular}

第 8 表 パターン D 詳細

\begin{tabular}{ccc}
\hline 弁開放割合 $(\%)$ & 流入割合 $(\%)$ & 累積流入割合 $(\%)$ \\
\hline 100 & 70 & 70 \\
\hline 60 & 4 & 74 \\
\hline 40 & 3 & 77 \\
\hline 20 & 3 & 80 \\
\hline 10 & 展開完了まで & 展開完了まで \\
\hline
\end{tabular}

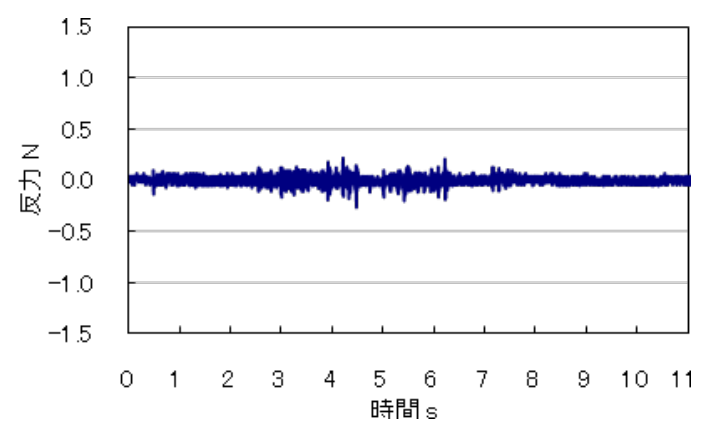

第 13 図 パターン D における反力 $(Y$ 軸方向 $)$

\section{4. 相似的に大きくした供試体での制御実験}

大規模構造物において本研究の制御の適用可能性を検 討するため，前章までに構築した制御方法が相似的に大き くした構造物においても同様の効果が得られるかについて 検討を行う。ここで相似的という表現については，チュー ブの材質や厚さは一定に保ったままで, 寸法のみを変化さ せたことを表す．特に構造物の寸法が変化したときの，制 御方法の適用や特徵を確認できれば本方法を多くの構造物 に応用することができる，そこで前章までに使用した供試 体の各寸法を 1.5 倍とした供試体 $\gamma$ について, 検討を行っ た．前章までに用いた供試体 $\beta$ での実験と同様に制御開始 より弁開放割合を各種設定し展開時の最大反力を測定する. その際前章と同様の内圧によるフィードバック制御を行う. 結果を第 14 図に示寸. 第 14 図より, 制御開始より弁開放 割合を 40 \%以下とすることで反力を低減出来ることがわ かる.ここで弁開放割合 $40 \%$ (流量 $12.35 \mathrm{~L} / \mathrm{min}$ ) は前章まで に使用した供試体での反力最小とする流量 $3.65 \mathrm{~L} / \mathrm{min}$ の 3.38 倍となっている. 本章において用いた供試体 $\gamma$ は供試 体 $\beta$ に比べて直径・全長がそれぞれ1.5倍としているため, 体積は 3.38 倍となっている.これよりインフレータブル構 造物の展開時の反力についての流量の特性は体積による相 
似性を有しているのではないかと予想される，そこで，前 章において用いた制御のパターン D とパターン Dの流量を 体積と同じ倍率にしたものについて検討を行う。ただし流 量を体積と同じ倍率としたときに最大流量である $30 \mathrm{~L} / \mathrm{min}$ を超えてしまうものに関しては流量を 30 L/min と設定した。 結果を第 9 表に示寸.第 9 表より,パターンDにおいても, その流量を体積と同じ倍率にしたものについても反力を低 減できていることが確認できる，つまり，相似的に大きく した構造物に対して相似的に流量を大きくして同様の制御 を行うことで反力を低減化し得る可能性があることを示し ている.

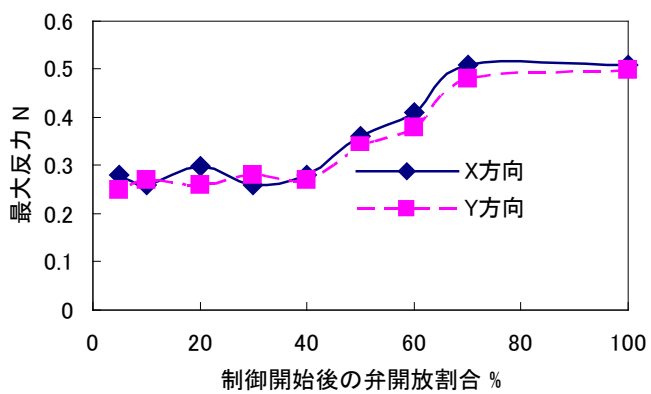

第 14 図 相似的に大きくした供試体 $(\gamma)$ においての実験結果

第 9 表 相似的に大きくした供試体 $(\gamma)$ への制御の適用結果

\begin{tabular}{cccc}
\hline \multirow{2}{*}{ パターン } & \multicolumn{2}{c}{ 最大反力 $(\mathrm{N})$} & \multirow{2}{*}{ 理論展開時間 } \\
\cline { 2 - 3 } & $X$ 方向 & $Y$ 方向 & $(\mathrm{s})$ \\
\hline 制御無し & 1.19 & 0.93 & 13.6 \\
\hline パターンD & 0.22 & 0.22 & 35.5 \\
\hline パターンD & 0.25 & 0.25 & 17.6 \\
体積比例の等価流量 & & & \\
\hline
\end{tabular}

\section{5. 結}

本研究では，マイコンを用いた内圧によるフィードバッ ク制御と電磁弁の制御を行い，内圧のフィードバックによ
るインフレータブルチューブの展開制御の有効性を確認し た。その結果，今回用いた供試体においては制御をしてい ない時と比較し，最大反力を約 80 \%低減できる結果を得た。 これにより，流量制御という簡素な構成で，展開時の反力 を低減できる最適な制御パターンの可能性を明らかにした。 同時に，相似的に大きくした供試体への実験を行うことに より，相似的に大きくした構造物において制御流量を相似 的に扱い得る可能性を有していることを確認した。これに より大型の構造においても本研究における制御手法の適用 は有効である見通しが得られた。

\section{参 考 文 献}

1) Grahne, M. S., Cadogan, D. P. and Lin, J. K. : Inflatable Solar Arrays Concept to Reality, 50th International Astronautical Congress, Amsterdam, IAF-99-I.1.09, 1999.

2) Guidanean, K. and Williams, G. T. : An Inflatable Rigidizable Truss Structure with Complex Joints, Proceedings of $39^{\text {th }}$ AIAA/ASME/AS CE/AHS/ASC Structures, Structural Dynamics and Materials Conference, Long Beach, AIAA-98-2105, 1998, pp. 2797-2806.

3) Freeland, R. E., Bilyeu, G. D., Veal, G. R. and Mikulas, M. : Inflatable Deployabale Space Structures Technology Summary, 49th IAF Congress, IAF-98-I.5.01, 1998.

4) Tsunoda, H., Senbokuya, Y. and Watanabe, M. : Deployment Characteristics Evaluation of Inflatable Tubes with Polygon Folding under Airplane Microgravity Environment, Space Technology, Lister Science, 25, 3-4 (2005), pp. 127-137.

5) Tsunoda, H. and Senbokuya, Y. : Deployment Characteristics of Rigidizable Space Inflatable Structures, Space Technology, Lister Science, 23, 2-3 (2003), pp.119-129.

6) 高野昌弘, 永田晴紀, 工藤 勲: インフレータブルチューブの無重 力環境における展開シミュレーション, 日本機械学会論文集 C 編, 65, 633 (1999), pp. 244-250.

7) 戸谷 剛, 潮 敬之, 永田晴紀, 工藤 勲: 折り目が残るインフレ 一タブルチューブの微小重力下での展開挙動, 日本機械学会論文 集 C 編, 67, 655 (2001), pp. 43-50.

8) Wang, J. T. and Johnson, A. R. : Deployment Simulation of UltraLightweight Inflatable Structures, $43^{\text {rd }}$ AIAA/ASME/ASCE/AHS/ASC Structures, Structural Dynamics, and Materials Conference, Denver, Colorado, AIAA-2002-1261, 2002.

9) Salama, M., Kuo, C. P. and Lou, M. : Simulation of Deployment Dynamics of Inflatable Structures, AIAA J., 38(2000), pp. 2277-2283.

10) 勝又暢久, 山川 宏: 衛星のスピン軸方向に伸展する超軽量アン テナの簡易モデル化と動的挙動に関する検討, 第 51 回宇宙科学技 術連合講演会論文集，2K15，2007. 